\title{
Insights About a Pandemic: Clinical Approach
}

\author{
Alicia García Falgueras* \\ Department of Psychology, Netherlands Institute for Neuroscience, Spain
}

*Corresponding author: Alicia García Falgueras, Department of psychology, Netherlands Institute for Neuroscience, Spain

\begin{abstract}
Many changes have occurred in our world in so many little time, as a novel situation that we all have had to cope with such as a sudden and unexpected pandemic. Psychological approaches such as skepticism, uncontrollability, new emotions to new stimuli, irrational thoughts or behaviors are some common consequences of the situation and we will elaborate them briefly in this text. Some basic clinical and medical explanations about the intermediate specie, common symptoms or possible brain affection are described in the text. With the perspective of a healthy future without viruses attacks, based on Scientific knowledge and the experience of producing laboratory experimental results.
\end{abstract}

\section{Introduction}

The global pandemic year 2020 has been a humanitarian challenge that affected everybody and has changed our lives and routines. Because of the sudden appearance, there is very few experts on Pandemic in the general population. Fear of disease has been daily present in our thoughts and worries in a much higher percentage: ten percent of patients infected with the SARS-CoV-2 generates a severe acute respiratory syndrome and becomes critical, requiring special care from the intensive care unit (UCI). The autoimmune response to this virus in the fight for self-cure might be disproportionate some cases, causing excessive swelling in vital organs which leads to incompatibilities to life. Skepticism and disbelief were common false friends present at the beginning of the spread of the plague. Uncertain or the complete absence of knowledge about its origin, its nature, its spreading behavior, how the metabolism might react, its effects over the organism, medicines to prevent (vaccine) or to cure, etc., were adding panic and fears to the situation, creating the ideal environment for corrupted approaches, faked information, shamanic cures, discrimination or unhealthy unsupportive responses. Government control measures meant in some cases extreme surveillance and complaints from neighbors without much evidence about other people behavior. An infected person could be forcibly examined and quarantined against his/her will. Scientific and clinical teams have worked hard together and improved our contrastable information about the virus and disease: a) the spread ration ( $\mathrm{R} 0=$ basic reproduction number) of this virus is higher than a normal flu ( $\mathrm{R} 0=2.5$ vs $\mathrm{R} 0=1.3$ ), b) the spread mechanism is so aggressive and long lasting (saliva which might remains over superficies for up several days). Coronaviruses over inanimate surfaces like metal plastic, metal or glass had been observed for up 9 days, being the minimal contact time for contagious of 30 seconds [1]. Some cases its effects over organism are of a considerable damage and harm for human life. Mean for incubation period is 5.2 days with the $95^{\text {th }}$ percentile of the distribution at 12.5 days [1], having the $80 \%$ of patient's mild symptoms but the amount of virus enough to spread it.

\section{Intermediate Specie}

The host creature for the virus was the bat, because of zoonoses, since this winged creature is the only mammal capable of powered flight for migration and having a longer range to spread the virus very rapidly, compared to land mammals. The most likely path of contaminations would be from the bat to the humans through saliva onto fomites or surfaces or through virus-laden aerosolized urine and faeces, with another intermediate specie (Figure 1) [2, 3]. Bats are able to maintain virus CoVs long-term without showing clinical symptoms or diseases [2]. Common spreader of diseases, the bat has been the inspiration for horror stories such as Dracula and vampires which needs to find new blood to drink for spreading the undead course. Many previous diseases such as Black Death, Spanish influenza, and HIV/AIDS, were caused by zoonoses LloydSmith [4]. Civets, horses, and great apes have been found to be 
intermediate species for several coronaviruses spreading and amplifying the virus, to subsequently infect humans [2,3].

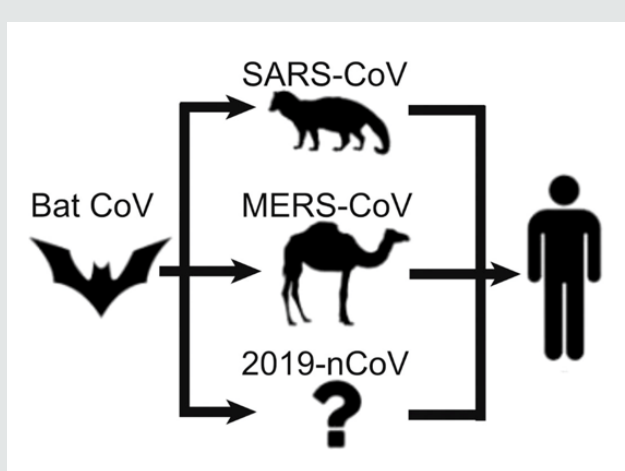

Figure 1: Examples of zoonoses. The path of SARS-Cov-2 or 2019-nCoV for COVID-19 remains unknown.

However, where the fist bat was infected to spill it over to humans remains unclear. How the virus survived outside of it reservoir host to contaminate the recipient host is known yet. The virus exposition had to be in sufficient quantity and time for generating an infection and disease in some intermediate specie. Health authorities are not able yet to accurately find and describe the Patient Zero in the Northern Italian outbreak [3, 5]. Progresses in understanding and combating zoonoses from Science would need a new generation of research schemas that addresses a broader approach of research with including several animals host species to study and several scientific disciplines all together [4].

\section{Skepticism or Denialism}

Cognitive skepticism is "an attitude of doubt or a disposition to incredulity either in general or in a particular object" . In 1980 Bertram Brookes published his pseudo-mathematical equation which he was working on for several years:

$$
K(S)+\Delta I=K(S+\Delta S)
$$

Where $K(S)$ means knowledge structure to be known and $\Delta \mathrm{I}$ the increase of information about the structure. In his own words, the equation "states in its very general way that the knowledge structure $K(S)$ is changed to the new modified structure $K$ (S $+\Delta S$ ) by the information $\Delta \mathrm{I}$, the $\Delta \mathrm{S}$ indicating the effect of the modification" $[6,7]$.. According to the formula, the bigger amount of information about the structure, the bigger change over the new knowledge compared to its original. Skepticism might be happening with a small bit of knowledge $(\Delta I)$ which remains the original and new structure almost identical. Concerning to the virus, skepticism might have happened at some point, when curative resources were aimed at the beginning for exaggerated cares to only a few first cases, without a clear perception of coming or priority risks [8].

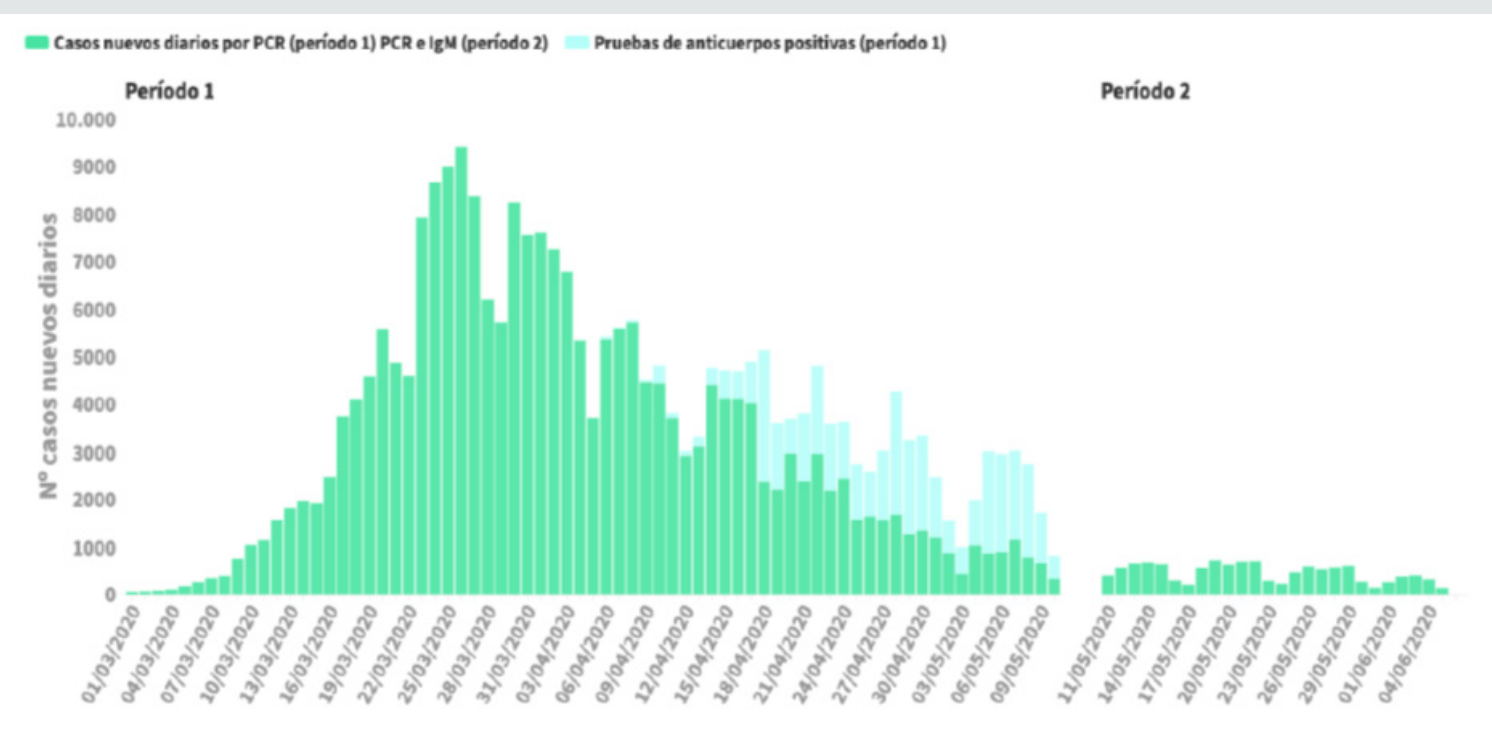

Figure 2: Spain COVID-19 diagnosed cases updated on June the $6^{\text {th }}$. Two periods of time are noticeable: first period from March to May and second period from May to June.

In Spain there has been 27.135 deceases (6-6-2020), 52 were professionals caregivers (Physicians, Nurses, Psychologist, etc.) from whom 40.961 have been infected (data Red Nacional de Vigilancia Epodemiológica 05-29-2020) (Figure 2). In the Netherlands due to the COVID-19 there was an excess of mortality of about 8,600 people in the period March 9 - May 10 according to the Central Bureau of Statistics (CBS). On the same day, RIVM announced that up to $28 \%$ of all registered contamination cases were healthcare workers, or about 8,000 cases. The risk of infection depends not only on personal risks factors, but also upon the general state of the other individuals in the population [4].

During first period and concurrently, different tests for diagnoses where made: positive antibodies tests (light green bars) and PCR, IgM (dark green bars). Second period only PCR and IgM were apply (dark green bars). From Centro de Coordinación de 
Alertas y Emergencias Sanitarias. Ministerio de Sanidad. Gobierno de España. So many Scientific publications are in the air and some has been published without time to contrast: experimental results are published within only 10 days of revision, being this way of information more similar to the daily News reports than to the rigorously procedure for Scientific texts. Publications based only in $\mathrm{N}=1$ patient have been accepted when that would be unthinkable for Journals in any other circumstances, when life is not under risk. Controlled experiments with manipulated variables compared to control groups and reviewers work would be desirable but were practically inexistent. However, difficulties of working with any sort of mammalian virus hinders such experimentation [3]. That causes contradictive information in a number of Scientific publications during pandemic time, without a calm or quiet study and reading other papers published.

However, Science still goes on and a promising treatment with a monoclonal antibody compound against COVID-19 Figure 3 has been experimentally checked in vitro with therapeutically efficacy in Thailand and Holland (Utrecht and Rotterdam) $[9,10]$. Neutralizing antibodies can alter the course of infection or protect against the virus [10], however large production of monoclonal antibodies might not be affordable in labor intensity, expenses and time consuming [9].

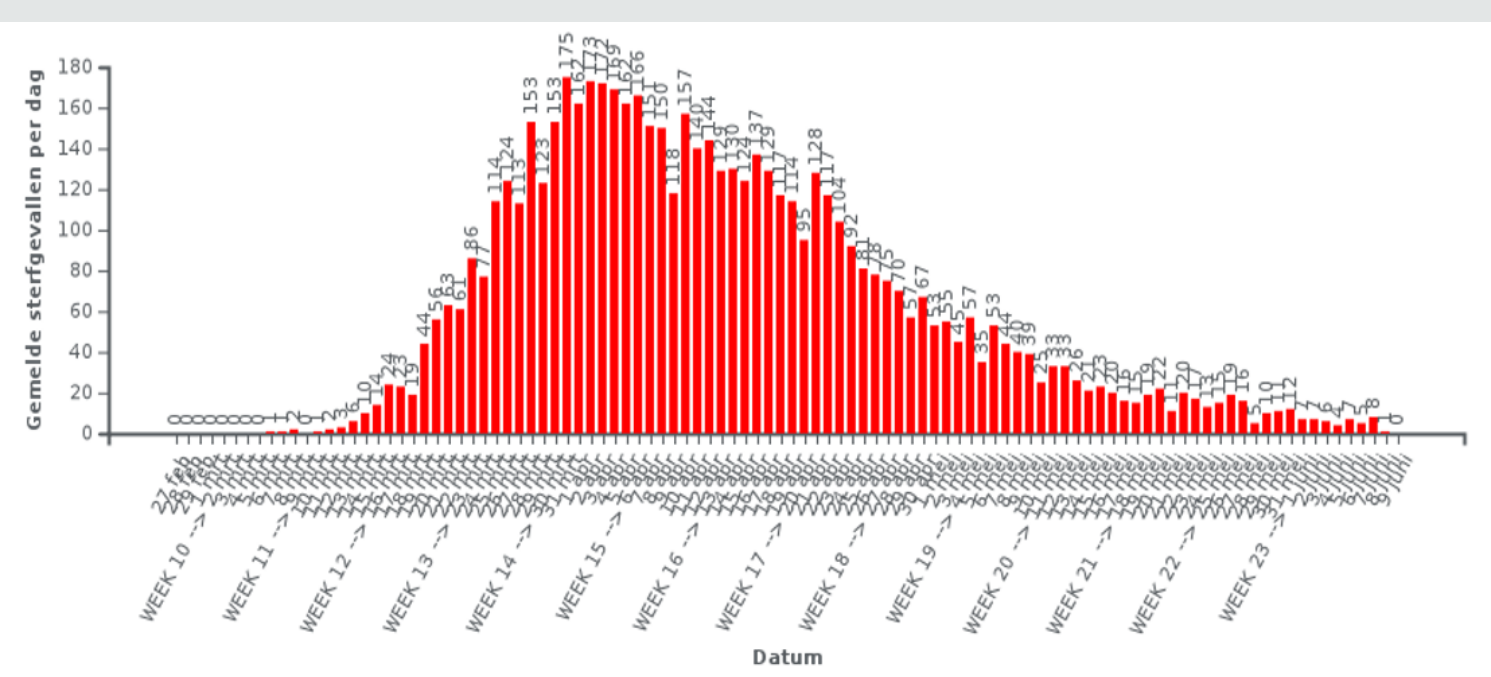

Figure 3: Dutch deceases reported by Rijksinstituut voor Volksgezondheid en Milieu (RIVM) by date of death (due to late reports, the figures will still change, reference date 9 June $10.00 \mathrm{am}$.

Likely a vaccine is going to be available in 2021 or earlier, because not only massive disease has to be prevented, but also some consequences for health and psychological sequels which are happening in patients after the disease. Inappropriate perception of the facts, worries about well-being of their families and irrational believes are some facts which are causing excessive stress response [11,12]. Parallel clinical diseases have been concurrently diagnosed in COVID-19 patients in relation to the stress, anxiety, immune-depression and also related to disseminated intravascular coagulation and blood coagulation alterations, leading to acral ischemia or dry gangrene [1, 13]. Autoimmune diseases concomitant to the disease COVID-19 or even to the lockout have been found: dermatological no specific reactions in children and adult were described, being unknown yet or remaining unclear whether they come up in response to an infection for the virus or to an emotional/hypersensible reaction [1,13], in some cases without hospitalization required. To an accurate diagnose, a number of reverse transcription polymerase chain reaction (RTPCR) kits with different primers and probes have been designed to detect SARS-CoV-2 presence genetically. Thermocyclers, incubation temperatures and times have been optimized to get the faster results: in the one-step assay, reverse transcription of SARS-CoV-2 and PCR amplification are happening into one unique simultaneously reaction [14].

Circulation of blood and changes in its coagulation pattern (thrombus, skin deceleration) were found, but no clarity whether they were a cause concurring with the infection or a consequence for the medication. Urticaria, morbilliform rash, vesicular eruptions, acral lesions ("COVID toes"), livedoid eruptions appeared in patients infected. Further microscopically analysis of the skin reveals groups of apoptotic keratinocytes in the epidermis, suggesting a viral exanthema [15]. Symptoms related to the loss of olfaction and taste during the infection COVID-19 (anosmia or hyposmia) were found in a few patients, likely due to the lower respiratory track diseases in uncomplicated early stage (fever, dry cough, weakness) [16-18].

A majority of Androgenetic Alopecia (79\%) in male patients and $42 \%$ in female patients has been coincident among patients hospitalized due to severe COVID-19 ("Gabrin sign"), suggesting a possible influence of the Androgen Receptor through its effect over the enzyme angiotensin-converting enzyme 2 (ACE2), both genes (AR, ACE2) located in chromosome X [16, 17, 19-21]. Some 
patients infected with SARS-CoV-2 showed neurological signs such as headache (about 8\%), nausea and vomiting (1\%) and in severe patients, acute cerebrovascular diseases and impaired consciousness [17]. Patients with acute SARS-CoV illness had evidences of the virus in their cerebrospinal fluid (Figure 4) [16]. In this brief revision we are exploring new emotions caused by several unpredictable situations due to the pandemic, irrational thoughts and we are including one psychological test for a better approach to a relocation of the locus of control.

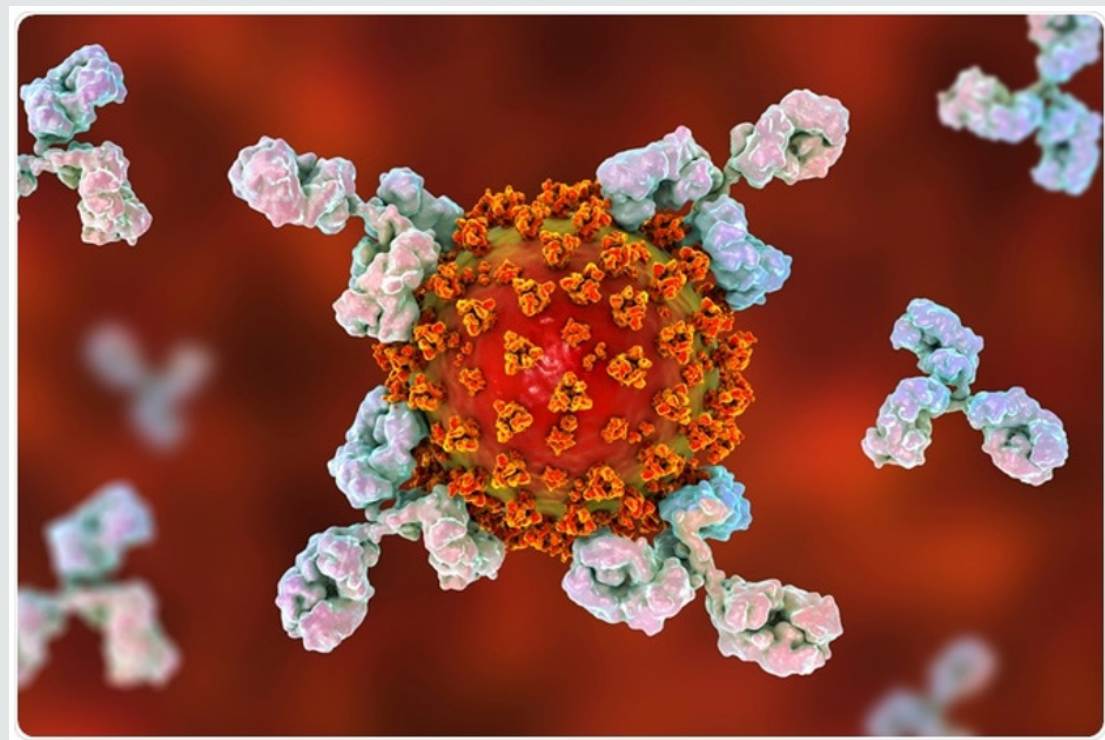

Figure 4: Conceptual 3D monoclonal antibody against the virus SARS-CoV-2. Image by Kateryna Kon/Shutterstock.

\section{New Emotions}

Ideas and believes might have a really huge impact over our health and metabolism: for instance, consumption of meat of wild animals has become a sign of social status in some areas of the world [22] and it seems the COVID-19 has been mainly caused for that rare habit. Education on these ideas with empirical data and contrasted information might be of great necessity to avoid further zoonoses. The strategies for preventing spread of outbreaks are mitigation (isolation plus quarantined plus social distancing) and suppression (isolation plus quarantined plus social distancing and closing schools, Universities and businesses). Those measures of isolation of confirmed and suspected cases and the rapid and effective contacts tracing of clinical cases have been succeeded for the majority of scenarios: with a R0 $=2.5$ the $70 \%$ of contacts were possible to be traced and isolation was assumed to be 100 $\%$ effective at preventing further transmission [23]. The word quarantine was firstly used in Venice, year 1127, when leprosy and later on with Black Death happened [24]. United Kingdom 300 years later established the quarantine as an imposition in response to a plague. All these measures imply a serious restriction for people's free will and their personal decisions, imposing the necessity of changing their routines, habits and lives till that moment. Some keys to deal with these hyper-protective measures to the subdued population were provided to the population, especially in order to prevent rebellions and for controlling the intensity of relief of de-escalated measures. Stigmatization and negative feelings, some of them negative against affected persons, also happened before in History (Spanish flu, bubonic plague, etc.). Even health care workers have suffered from a greater stigmatization and rejection from people in their local neighborhoods than the general public [24].

Post-traumatic stress symptoms, confusion, anger, exhaustion, mass hysteria, obsession of contamination, detachment from others, anxiety, indignation, irritability, frustration, boredom, financial loss, annoyance, fear, isolation, helplessness, loneliness, less happiness, etc. are some consequences described which have an impact over our psychological state and the general population $[11,24,25]$. Stigmatizations causes damage in psychological health and common coexistence, that is why the World Health Organization (WHO) have tried to prevent it from the very beginning, renaming on February the $11^{\text {th }}$ the disease as COVID-19 [16], with no link to the area or region where it firstly showed up to avoid discrimination against Chinese population.

The enemy is the virus, but many unreasonable behaviors might have happened because our inertial reactions to blame something else and because our psychological necessity of visualizing the hated target. Worries of people changed to be mainly focus on their health and family instead of in leisure and friends [11]. Victimization is an approach that patients with severe sequels might apply themselves, because in some cases posterior to the infection a long time has to be dedicated to rehabilitation therapies. Social distancing together with barrier methods (facial masks) and respiratory hygiene (washing hands and good breathing habits) are 
some keys suggested to avoid disease and improve general health [25]. In children a relative resistance to SARS-CoV-2 has been described, however the reason why is not clear yet [26].

But as human spirit uses to do, also good emotions and feelings happened: for instance an increase in faith for Science and its curative labor during these months, because a vaccine would be a very efficient measure and perhaps the only one, to reduce anxiety and fears on general population. Messages about death and religion became salient to comfort tense moods and bring more positive emotions, after January $20^{\text {th }}$ when Dr. Zhong Nan Shan made a public announcement of this virus in CCTV $[11,18]$. Music, routine games, allowed recreational activities and generous musical and artistic performances have been shared between common people and neighborhoods every day. King of the Netherlands WillemAllexander comforted and warned people to avoid loneliness: "Alertness, solidarity and warmth: as long as we keep those three, we can handle this crisis together, even if it takes a little longer." King said. In Spain admiration and respect have been shown everyday with applauses toward the caregivers and their current difficult work. As Sir Ludwig Guttmann said, "this is especially the time we need to "love our paraplegics" [27].

\section{Irrational Thoughts And Behaviors}

Our common enemy is a virus which is a target not visible. Understanding about that fact is not an easy goal. The lockout has reduced social interactions or hobbies to be distracted, then an increase in bad, harmful, and toxic habits (alcohol, drugs) and thoughts through rumination has happened. Under these unexpected circumstances with any or few psychological tools to deal, people are more likely to develop negative emotions (aversion, anxiety) and negative cognitive assessment about self-protection, life satisfaction or social risks, which may result in excessive avoidance behaviors and blind conformity [11].

Some behaviors as repeated washing hands like an obsessivecompulsive disorder (OCD) might be "normalized" and even socially rewarded in the middle of the pandemic [25]. The OCD and specifically its compulsive nature is clinically defined by the DSM- 5 (300.3) as: "1. Repetitive behaviors (e.g., hand washing, ordering, checking) or mental acts (e.g. praying, counting, repeating words silently) that the individual feels driven to perform in response to an obsession or according to rules that must be applied rigidly." However, the temporal criteria makes the diagnoses more restrictive: $\mathrm{B}$. The obsessions or compulsions are time-consuming (e.g., take more than 1 hour per day). About the prevalence: The 12-month prevalence of OCD in the United States is $1.2 \%$, with a similar prevalence internationally $(1.1 \%-1.8 \%)$.

The frustration related to quarantine goes to several psychological problems including depression and post-traumatic stress disorder. Post-traumatic stress disorder is typified by recurrent, extremely vivid memories of traumatic events and the avoidance of everything that brings them to mind, along with depression, addiction, increased watchfulness, aggression, shame, nightmares, flashbacks, feelings of guilt, raised heart-rate, shallow sleep, frequented waking and excessive irritability ("having a short fuse") [28, 29]. Moreover this environment pushes people to consume high sugar foods (chocolate, soft drinks, saturated fats) to boost their mood and release dopamine in the brain, which increases obesity. Sleep disturbances also increases food intake and physical activities has been reduced because to the lockdown, to the point some countries should be prepared for the upcoming epidemic of "depreobessed patients" [30]. Anxiety, depression, indignation and other negative cognitive indicators were wildly described in an affected population [11]. Physical exercises might be a good solution to prevent obesity, to a better sleep and healthy breathing space habits and for our immune system [31, 32].

\section{Locus of Control Internal Vs External}

The concept of locus of control was firstly described by Julian B. Rotter in 1954, referring to a personality trait based on the degree that people believe to have about their own control over the outcome of events vs the power of external forces beyond their particular influence (Figure 5). Attributional styles and self-efficacy concepts are built upon this trait, which may lead to neuroticism, poor self-efficacy or low self-esteem. In Figure 5: Metaphorical representation of an external locus of control, being the subject unable to freely move or to think without instructions coming from their ties. In order to restore our confidence and start new fresh acting on our internal locus of control areas and to learn from our mistakes, we suggest to read and answer this inventory elaborated by Rotter, to improve our knowledge about differences in loci of control and to get a better perspective of our own power over the events [33]. Many external places are suggested in this questionnaire as "common areas to blame" as responsible for our own decisions and paths taken: politicians, teachers, leaders, mates, friends, parents, genes, conflicts, luck, accidents, few trials, etc (Table 1). 


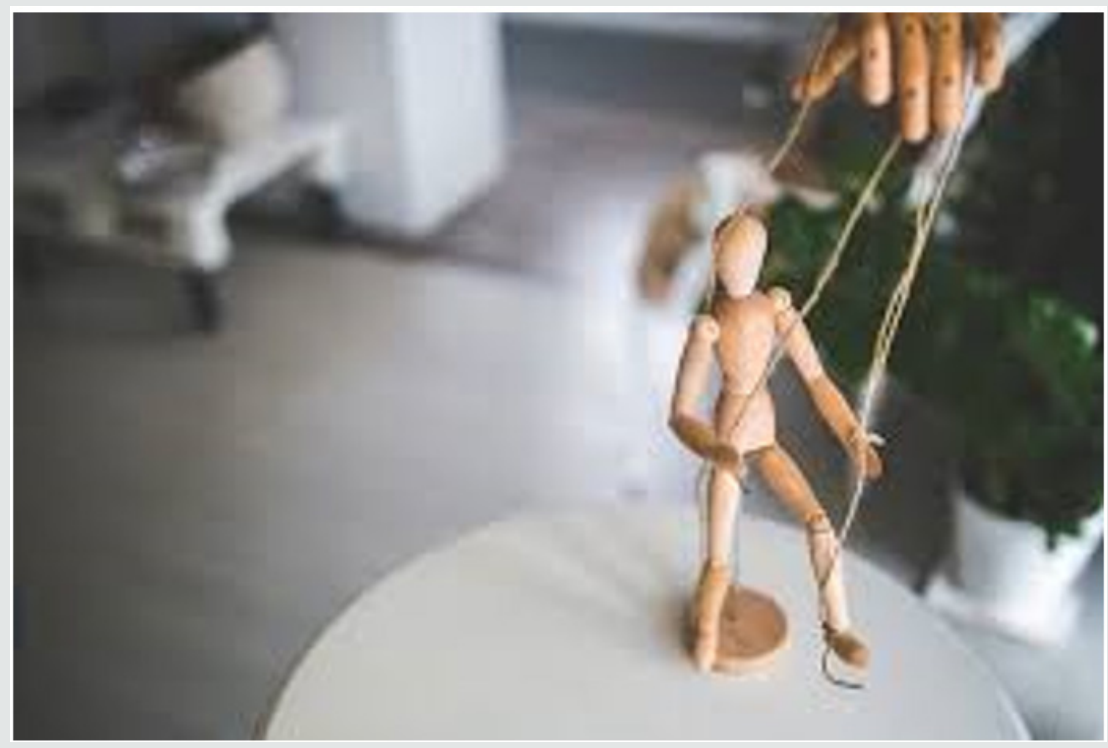

Figure 5: Metaphorical representation of an external locus of control, being the subject unable to freely move or to think without instructions coming from their ties.

Table 1: Rotter Internal-External Locus of Control Scale. The subject is asked to answer, either ' $a$ ' or ' $b$ ' to each question on this inventory.

\begin{tabular}{|c|c|c|}
\hline \multirow{2}{*}{1} & a) & Children get into trouble because their parents punish them too much. \\
\hline & b) & The trouble with most children nowadays is that their parents are too easy with them. \\
\hline \multirow{2}{*}{2} & a) & Many of the unhappy things in people's lives are partly due to bad luck. \\
\hline & b) & people's misfortunes result from the mistakes they make. \\
\hline \multirow{2}{*}{3} & a) & One of the major reasons why we have wars is because people don't take enough interest in politics. \\
\hline & b) & There will always be wars, no matter how hard people try to prevent them. \\
\hline \multirow{2}{*}{4} & a) & In the long run people get the respect they deserve in this world. \\
\hline & b) & Unfortunately an individual's worth often passes unrecognized no matter hard he tries. \\
\hline \multirow{2}{*}{5} & a) & The idea that teachers are unfair to students is non-sense. \\
\hline & b) & Most students don't realize the extent to which their grades are influenced by accidental happenings. \\
\hline \multirow{2}{*}{6} & a) & Without the right breaks one cannot be an effective leader. \\
\hline & b) & Capable people who fail to become leaders have not taken advantage of opportunities. \\
\hline \multirow{2}{*}{7} & a) & No matter how hard you try some people just don't like you. \\
\hline & b) & People who cannot get others to like them don't understand how to get along with others. \\
\hline \multirow{2}{*}{8} & a) & Heredity plays the major role in determining one's personality. \\
\hline & b) & It is one's experiences in life which determine what they are like. \\
\hline \multirow{2}{*}{9} & a) & I have often found that what is going to happen will happen. \\
\hline & b) & Trusting to fate has never turned out as well for me as making a decision to take a definite course of action. \\
\hline \multirow{2}{*}{10} & a) & In case of the well prepared students there is rarely if ever such a thing as an unfair test. \\
\hline & b) & many times exam question tend to be so unrelated to course work that studying is really useless. \\
\hline \multirow{2}{*}{11} & a) & Becoming a success is a matter of hard work, luck has little or nothing to do with it. \\
\hline & b) & Getting a good job depends mainly on being in the right place at the right time. \\
\hline \multirow{2}{*}{12} & a) & The average citizen can have an influence in Government decisions. \\
\hline & b) & The world is run by the few people in power, and there is not much the little guy can do about it. \\
\hline \multirow{2}{*}{13} & a) & When I make plans, I am almost certain that I can make them work. \\
\hline & b) & It is not always wise to plan too far ahead because many things turn out to be a matter of good or bad fortune anyhow. \\
\hline \multirow{2}{*}{14} & a) & There are certain people who are just no good. \\
\hline & b) & There is some good in every body. \\
\hline
\end{tabular}




\begin{tabular}{|c|c|c|}
\hline \multirow{2}{*}{15} & a) & in my case getting what I want has little or nothing to do with luck. \\
\hline & b) & Many times we might just as well decide what to do by flipping a coin. \\
\hline \multirow{2}{*}{16} & a) & Who gets to be the boss often depends on who was lucky enough to be in the right place first. \\
\hline & b) & Getting people to do the right thing depends upon ability; luck has little or nothing to do with it. \\
\hline \multirow{2}{*}{17} & a) & As far as world affairs are concerned, most of us are victims of forces we can neither understand nor control. \\
\hline & b) & By taking an active part in politics and social affairs the people can control the world events. \\
\hline \multirow{2}{*}{18} & a) & Most people can't realize the extent to which their lives are controlled by accidental happenings. \\
\hline & b) & There really is no such thing as "luck". \\
\hline \multirow{2}{*}{19} & a) & One should always be willing to admit his mistakes. \\
\hline & b) & It is usually best to cover one's mistakes. \\
\hline \multirow{2}{*}{20} & a) & It is hard to know whether or not a person really likes you. \\
\hline & b) & How many friends you have depends upon how nice a person you are. \\
\hline \multirow{2}{*}{21} & a) & In the long run the bad things that happen to us are balanced by the good ones. \\
\hline & b) & Most misfortunes are the result of lack of ability, ignorance, laziness or all three. \\
\hline \multirow{2}{*}{22} & a) & With enough effort we can wipe out political corruption. \\
\hline & b) & It is difficult for people to have much control over the things. \\
\hline \multirow{2}{*}{23} & a) & Sometimes I can't understand how teachers arrive at grades they give. \\
\hline & b) & There is a direct connection between how hard I study and the grades I get. \\
\hline \multirow{2}{*}{24} & a) & A good teacher expects people to decide for themselves what they should do. \\
\hline & b) & A good teacher makes it clear to everybody what their jobs are. \\
\hline \multirow{2}{*}{25} & a) & Many times I feel that I have little influence over the things that happen to me. \\
\hline & b) & It is impossible for me to believe that chance or luck plays an important role in my life. \\
\hline \multirow{2}{*}{26} & a) & People are lonely because they don't try to be friendly. \\
\hline & b) & There is not much use of trying too hard to please people, if they like, they like you. \\
\hline \multirow{2}{*}{27} & a) & there is too much emphasis on athletics in high school. \\
\hline & b) & Team sports are an excellent way to build character. \\
\hline \multirow{2}{*}{28} & a) & What happens to me is my own doing. \\
\hline & b) & Sometimes I feel that I don't have enough control over the direction my life is taking. \\
\hline \multirow{2}{*}{29} & a) & Most of the time I can't understand why politicians behave the way they do. \\
\hline & b) & In the long run the people are responsible for bad Government on a national as well as on a local level. \\
\hline
\end{tabular}

During the lockout and because of pandemic restrictions, locus of control of people has been dramatically changed to be almost completely external to their will, with the sudden imposition of new rules which changed their control over their routines and lives. No chance of choosing about where to be or what to do, because suppression measures closed every places people used to go. Under this extremes circumstances, the locus of control might be relocated and focused on smaller areas where the person has a real control, such as the time of their days, the space of their homes, the few indoor activities, etc. Much more creativity and imagination are required from population, who is asked to keep calm and be patient while their range of maneuvering is considerable limited and restricted. Uncomfortable forced coexistence might lead to many conflicts that might be avoid: confusion about who is the enemy, the easily spread of fake news, rumors or even magic cures about the disease, passive and victimizes attitudes in healthy people, personalization of the information given by media or newspapers about the pandemic.

\section{Conclusion}

With this virus and at a very high cost we have learned several important lessons. Among them, the humble assumption that a tiny creature without superior intelligence or brain is capable of putting us in check and making us tremble at the foundations of our civilization. For the virus itself it is not a matter of ideology or power, or right or wrong, or races nor colors, or amount of military arsenal. Another lesson would be the fact that every person has its own immune system and reacts differently to the same virus. Every disease each people has suffered makes the history of his/her immune system which allows a particular fight against the virus. Among all our immune systems, the virus is mutating and we are working in a team against the common enemy. We, as a specie with brain and higher intelligence, will find hopefully soon safe vaccines for everybody according to their body weights and metabolism.

\section{Acknowledgement}

We thank Prof. Dr. D. F. Swaab for his teachings and research 
method orientations. Dutch information in this text comes from him and his collaborative orientation has been essencial for the understanding of the pandemic situation.

\section{References}

1. Wollina U (2020) Challenges of COVID-19 pandemic for dermatology. Dermatol There 13430.

2. Fan Y, Zhao K, Shi ZL, Zhou P (2019) Bat Coronaviruses in China. Viruses 11(3):200-210.

3. Plowright RK, Eby P, Hudson PJ, Ina L Smith, David Westcott, et al. (2015) Ecological dynamics of emerging bat virus spillover. Proc Biol Sci 282:0142124.

4. Lloyd Smith JO, George D, Pepin KM, Virginia E Pitzer, Juliet RC Pulliam, et al. (2009) Epidemic dynamics at the human-animal interface. Science 326:1362-1367.

5. Porcheddu R, Serra C, Kelvin D, Kelvin N, Rubino S (2020) Similarity in Case Fatality Rates (CFR) of COVID-19/SARS-COV-2 in Italy and China. The Journal of Infection in Developing Countries 14:125-128.

6. Giarlo MJ (2006) The role of skepticism in human-information behavior: a cognitive-affective analysis. Information and Library Studies p:1-16.

7. Brooks SK, Webster RK, Smith LE, Lisa Woodland, Simon Wessely, et al. (2020): The psychological impact of quarantine and how to reduce it: rapid review of the evidence. Lancet 395(10227):912-920.

8. Glauser W (2020) Proposed protocol to keep COVID-19 out of hospitals. CMAJ 192(10):E264-E265.

9. Shanmugaraj B, Siriwattananon K, Wangkanont K, Phoolcharoen W (2020) Perspectives on monoclonal antibody therapy as potential therapeutic intervention for Coronavirus disease-19 (COVID-19). Asian Pac J Allergy Immunol 38(1):10-18.

10. Wang C, Li W, Drabek D, Nisreen MA Okba, Rien Van Haperenet, al. (2020) A human monoclonal antibody blocking SARS-CoV-2 infection. Nature Communication 11:2250-2251.

11. Li S, Wang Y, Xue J, Zhao N, Zhu T (2020) The Impact of COVID-19 Epidemic Declaration on Psychological Consequences: A Stu dy on Active Weibo Users. Int J Environ Res Public Health 17(6):2030-2032.

12. Liew MF, Siow WT, MacLaren G, See KC (2020) Preparing for COVID-19: early experience from an intensive care unit in Singapore. Crit Care 24(1):80-83.

13. Fernandez Nieto D, Jimenez Cauhe J, Suarez Valle A, Oscar M Moreno Arrones, David Saceda Corralo, et al. (2020) Characterization of acute acro-ischemic lesions in non-hospitalized patients: a case series of 132 patients during the COVID-19 outbreak. J Am Acad Dermatol 83(1):e61-e63.

14. Udugama B, Kadhiresan P, Kozlowski HN, Ayden Malekjahani, Matthew Osborne, et al. (2020) Diagnosing COVID-19: The Disease and Tools for Detection. ACS Nano 14(4):822-3835.

15. Young S, Fernandez AP (2020) Skin manifestations of COVID-19. Cleve Clin J Med.
16. Baig AM, Khaleeq A, Ali U, Syeda H. (2020): Evidence of the COVID-19 Virus Targeting the CNS: Tissue Distribution, Host-Virus Interaction, and Proposed Neurotropic Mechanisms. ACS Chem Neurosci 11(7):995-998.

17. Li YC, Bai WZ, Hashikawa T (2020) The neuroinvasive potential of SARSCoV2 may play a role in the respiratory failure of COVID-19 patients. Journal of Medical Virology 92(6):552-555.

18. Hua J, Shaw R (2020) Corona Virus (COVID-19) "Infodemic" and Emerging Issues through a Data Lens: The Case of China. Int J Environ Res Public Health 17(7):2300-2309.

19. Wadman, Meredith (2020) Sex Hormones signal why virus hits men harder. Science 5:1038-1039.

20. Wambier CG, Vaño Galván S, McCoy J, Alba Gomez Zubiaur , Sabina Herrera, et al. (2020) Androgenetic Alopecia Present in the Majority of Hospitalized COVID-19 Patients the "Gabrin sign". J Am Acad Dermatol 83(2):680-682.

21.Wambier CG, Goren A. (2020) Severe acute respiratory syndrome coronavirus 2 (SARS-CoV-2) infection is likely to be androgen mediated. J Am Acad Dermatol 83(1):308-309.

22. Brüssow H (2020) The Novel Coronavirus-A Snapshot of Current Knowledge. Microb Biotechnol 13(3):607-612.

23. Hellewell J, Abbott S, Gimma A, Nikos I Bosse , Christopher I Jarvis ,et al. (2020) Feasibility of controlling COVID-19 outbreaks by isolation of cases and contacts. The Lancet Global Health 8(4):e488-e496.

24. Brookes BS (1980) The foundations of information science, part I, Philosophical aspects. Journal of Information Science 2(3-4):125-134.

25. Banerjee DD (2020) The other side of COVID-19: Impact on obsessive compulsive disorder (OCD) and hoarding. Psychiatry Res 288:112966.

26. Lee PI, Hu YL, Chen PY, Huang YC, Hsueh PR (2020) Are children less susceptible to COVID-19? J Microbiol Immunol Infect 53(3):371-372.

27. Alexander M (2020) Let's conquer COVID-19 and sustain our abilities. Spinal Cord Ser Cases. Spinal Cord Ser Cases 6(1):10-19.

28. Swaab D (2019) Our Creative Brains. Atlas Contact, Uitgeverij.

29. Garcia Falgueras Alicia (2019) Seguridad Psicológica y Trastorno de Estrés Post-traumático. Cuadernos de Seguridad 344:80-83.

30. Mediouni M, Madiouni R, Kaczor Urbanowicz KE (2020) COVID-19: How the Quarantine could lead to the Depreobesity. Obesity Medicine 19:100255.

31. Garcia Falgueras Alicia (2015) Psychological benefits of sports and physical activities. British Journal of Medicine and Medical Research 15:1-7.

32. Garcia Falguera Alicia (2019) Physical Health TK Shackelford, VA Weekes-Shackeldord (Eds.), Encyclopedia of Evolutionary Psychological Science, $P$ entrance: 1-5.

33. Rotter JB (1967) A new scale for the measurement of interpersonal trust. J Pers 35(4):651-665. 


\section{(C) This work is licensed under Creative}

To Submit Your Article Click Here:

Submit Article

DOI: $10.32474 /$ SJPBS.2020.04.000185

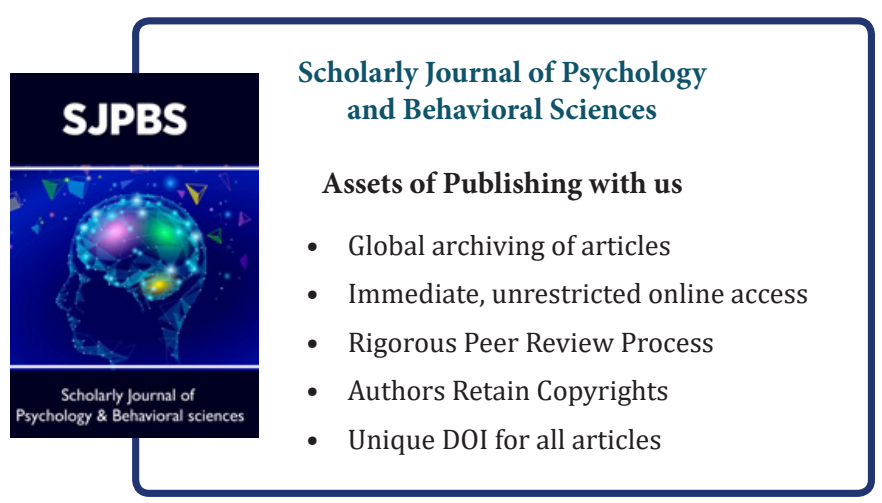

